\title{
Extent of Adoption of Bangladesh Rice Research Institute (Brri) Recommended Boro Rice Varieties
}

\author{
Sumana Reza Juthi ${ }^{1}$, Mohammad Bashir Ahmed ${ }^{1}$, Maruf Billah $^{1}$, Ruhul Amin ${ }^{2}$ and Manash Mohan Adhikary ${ }^{3 *}$ \\ ${ }^{1}$ Student, Professor and Lecturer, Agrotechnology Discipline, Khulna University, Khulna, Bangladesh \\ ${ }^{2}$ Professor, Department. of Agricultural Extension Education, Sylhet Agricultural University, Sylhet, Bangladesh \\ ${ }^{3}$ Professor, (Rtd), Department. of Agricultural Extension and Former Vice-Chancellor, Bidhan Chandra Krishi Vishwavidyalaya, Madhapur, \\ Nadia, WB, India \\ *Corresponding Author: Manash Mohan Adhikary, Professor, (Rtd), Department of Agricultural Extension and Former Vice-Chancellor, \\ Bidhan Chandra Krishi Viswavidyalay, Mohanpur, Nadia, WB, India.
}

Received: September 19, 2019; Published: October 18, 2019

DOI: 10.31080/ASAG.2019.03.0688

\begin{abstract}
The study was carried out with the aim to determine the extent of adoption of BRRI recommended boro rice varieties by the boro farmers. Data were collected from randomly selected 80 respondents through personal interview method during January-February, 2019. The findings of the study revealed that majority (77.5\%) of the respondents belonged to high adoption category while $16.3 \%$ of the respondents of were medium and low (6.3\%) adoption categories. Adoption of BRRI dhan28 occurred to greater extent in the study area due to its early maturity, less water requirement, high market price, non- complexity of cultivation procedure. Correlation analysis indicated that among the selected socio- economic characteristics, exposure to communication media and cosmopoliteness of the respondents showed a significant positive relationship with their extent of adoption while educational qualification, family size, farm size, innovativeness and attitude showed positive non-significant relationship with their extent of adoption. On the other hand, age, farming experience, experience in rice cultivation, experience in boro rice cultivation, family education, annual income and organizational participation showed negative non-significant relationship.
\end{abstract}

Keywords: Extent of Adoption; BRRI, Boro Rice Varieties; Farmers'

\section{Introduction}

Bangladesh has an agrarian economy in which rice is the dominant crop. In Bangladesh, about $76 \%$ of the people live in rural areas, and $47.5 \%$ of the total manpower is involved in agriculture [1]. Water stagnation, salinization, erosion and human settlements lead to the loss of rice fields in an alarming speed in many countries. Densely populated country like Bangladesh desperately needs substantial increases in crop production to provide her teeming millions with food. In Bangladesh, agriculture contributes $19.3 \%$ of the gross domestic product (GDP) of the country [2]. There are three rice-growing seasons in Bangladesh: aus, aman, and boro. Some areas under aus cultivation have shifted to irrigat- ed boro rice because of the high yield potential of boro rice. Boro is the dry-season irrigated rice planted from December to early February and harvested between April and June. Nearly $91.77 \%$ of the 4.08 million hectares of boro is planted with modern varieties [1]. The precondition for growing high yielding varieties in boro season is proper water management. Bangladesh Rice Research Institute (BRRI) was established in October, 1970 in Joydebpur, Gazipur. The Institute has an outstanding contribution to the food security of Bangladesh. So far it has developed 67 high yielding rice varieties including four hybrid ones. Moreover, these varieties are cultivated in about 80 percent of the total rice areas and contribute almost 91 percent of total rice production of the country [3]. Since 
1973, the Bangladesh Rice Research Institute (BRRI), in partnership with IRRI, has been engaged in adaptive research to evaluate elite genetic lines under the IRRI-managed International Network for Genetic Evaluation of Rice (INGER). Under the brand name BR, and later BRRI dhan, it has released varieties that suit the agroecological conditions in Bangladesh [4]. BRRI had developed some salt tolerant boro rice varieties for coastal area because the coastal saline soils are distributed unevenly in 64 upazila of 14 districts, covering 8 agro-ecological zones (AEZ) of the country. But this vast area of land could not have contributed in agricultural production or development due to increasing salinity. Salinity is a year-round problem in the coastal Bangladesh but its intensity reaches peak during the dry season (January- May) and for that reason boro rice crop suffers the most [5]. There has been tremendous change in adoption of boro variety in the south-western part of Bangladesh. Farmers are eagerly adopted BRRI recommended boro rice varieties because of its higher production than traditional. In this study, an effort has been made to identify the existing popular BRRI recommended boro rice variety as well as their extent of adoption and measure the influence of selected characteristics of the farmers' on extent of adoption of BRRI recommended boro rice varieties in the selected study area.

\section{Materials and Methods}

Design and locale of research

The study was a descriptive and diagnostic type of research. The study was conducted at four selected villages namely Raingamari, Dorgatola, TheraBand and Shoilmari of Jalma union under Batiaghata upazila of Khulna district of Bangladesh which were selected following multistage random sampling method.

Population and sampling design

The sample was drawn by following multistage random method. All the boro rice growers of selected four villages of Jalma union under Batiaghata upazila of Khulna district of Bangladesh constituted the population of the study. For data collection, 10\% upazilas out of total upazilas in Khulna district were selected and then $10 \%$ union from each upazila and 10\% villages from each union were selected. A total of 80 farmers were selected randomly as sample taking 20 farmers from each of the villages irrespective of their population size.

\section{Data collection}

Data were collected through personal interview method by the researcher herself using an interview schedule during January-
February, 2019. Both open and closed form, simple and direct questions were included in the interview schedule. The questions were systematically arranged to help the respondents to comprehend the consequence easily. Before final collection of data, the interview schedule was pre-tested. Necessary correction, addition, alteration and rearrangements were made after pre-testing. In survey research specification and measurement of the variables constitute an important task. A well organized research hypothesis consists of at least two elements-

1. Independent variable and

2. Dependent variable

Fifteen selected characteristics of the respondents were treated as independent variable for this study. The selected characteristics were age, education, farming experience, experience in rice cultivation, experience in boro cultivation, family size, family education, farm size, annual income, organizational participation, cosmopoliteness, exposure to communication media, training exposure, attitude towards boro cultivation and innovativeness. Extent of adoption of BRRI recommended boro rice varieties was considered as dependent variable of the study.

All the qualitative data were converted into quantitative form by means of suitable code and score whenever necessary. In several instances indices and scales were constructed through simple accumulation of scores assigned to individual or pattern of attributes. Indices and scales are considered the efficient instrument for data collection and analysis.

Measurement of selected characteristics (Independent Variables)

The measurement of selected characteristics (independent variables) is shown in table 1 .

Extent of adoption of BRRI recommended boro rice varieties of the respondents

Adoption is a decision to make full use of innovation as the best course of action available [6]. When an individual takes up a new idea as the best course of action and practices it, the phenomenon is known as adoption. BRRI has recommended some varieties such as BRRI dhan47, BRRI dhan28, BRRI dhan29, BRRI dhan50, BR - 26 etc. for cultivation in the coastal region. But unfortunately, the respondents adopted only BRRI dhan 28 as boro rice for cultivation. So, the extent of adoption of BRRI dhan28 is shown in subsequent 
section rather BRRI recommended all varieties for coastal region. The extent of adoption of BRRI recommended boro rice varieties was measured by percentage of area covered by BRRI recommended boro rice varieties by using the following formula:

Extent of Adoption $=\mathrm{A}_{\mathrm{a}} / \mathrm{P}_{\mathrm{a}} \times 100$

Where, $A_{a}=$ Actual area of adoption of BRRI recommended boro rice varieties.

$\mathrm{P}_{\mathrm{a}}=$ Potential area for adoption of boro rice varieties.

Adoption of BRRI recommended boro rice varieties was expressed in percentage. Based on the adoption score, the respondents were also classified into three categories as shown in Table.

\begin{tabular}{|l|c|}
\hline $\begin{array}{l}\text { Selected characteristics } \\
\text { (independent variables) }\end{array}$ & Measuring Unit \\
\hline Age & Actual year \\
\hline Educational qualification & Years of schooling \\
\hline Farming experience & Years \\
\hline Experience in rice cultivation & Years \\
\hline Experience in boro cultivation & Years \\
\hline Family size & Number \\
\hline Family education & Years of schooling \\
\hline Farm size & Hectare \\
\hline Annual income & ‘00’BDT \\
\hline Organizational participation & Score \\
\hline Cosmopoliteness & Score \\
\hline Exposure to communication media & Score \\
\hline Training exposure & Score \\
\hline Attitude towards boro cultivation & Score (following \\
& Likert scale) \\
\hline Innovativeness & Years \\
\hline
\end{tabular}

Table 1: Measurement of selected characteristics (independent variables).

\begin{tabular}{|l|c|}
\hline Categories & Score (\%) \\
\hline Low adoption & $\leq 60$ \\
\hline Medium adoption & $60-80$ \\
\hline High adoption & $>80$ \\
\hline
\end{tabular}

Table
Data analysis

After collection, data were analyzed and tabulated for interpretation. Statistical treatments such as number, mean, standard deviation, range, rank order etc. were used to interpret data. To explore relationship between any two variables Pearson's product correlation coefficient (for interval and ratio type data), Spearman rank correlation coefficient (for ordinal type data) were employed. For analysis of data Statistical Package for Social Science (SPSS) version 20 was used.

\section{Results and Discussion}

\section{Characteristics of the respondents}

Data presented in table 2 indicate that most (92.5\%) of the respondents were middle to old aged. The majority of the respondents had secondary level of education (53.8\%), medium farming experience (58.8\%), medium experience in rice cultivation (53.8\%). Highest proportion of the respondents were highly experienced in boro rice cultivation (40\%) and had medium income (46.3\%), About three-fourth of the respondents belonged to the small sized family (75\%) and secondary level of family education $(72.5 \%)$. Most of the respondents possessed small farm size (91.3\%), had low level of organizational participation (86.3\%) and had moderately favorable attitude (96.3\%). Majority of the respondents had high cosmopoliteness (55.0\%) and received training on farming activities (65\%). Besides, more or less three-fourth of the respondents had medium scale exposure to communication media (78.8\%) and were early majority in adopting BRRI recommended boro rice varieties $(71.3 \%)$.

Identification of boro rice as cultivated by the farmers of study area

BRRI has recommended some varieties such as BRRI dhan47, BRRI dhan28, BRRI dhan29, BRRI dhan50, BR-26 etc. for cultivation in the coastal region. But unfortunately the respondents adopted only BRRI dhan 28 as boro rice for cultivation. So, the extent of adoption of BRRI dhan28 is shown in subsequent section rather BRRI recommended all varieties for coastal region. 


\begin{tabular}{|c|c|c|c|c|c|c|c|c|}
\hline \multirow[b]{2}{*}{ Characteristics } & \multirow[b]{2}{*}{ Categories } & \multirow[b]{2}{*}{ Score } & \multicolumn{2}{|c|}{ Respondents(N=80) } & \multirow[b]{2}{*}{ Mean } & \multirow[b]{2}{*}{ SD } & \multicolumn{2}{|c|}{ Range } \\
\hline & & & Number & $\begin{array}{c}\text { Percentage } \\
\text { (\%) }\end{array}$ & & & Min & Max \\
\hline \multirow[t]{3}{*}{ Age(Year) } & Young & $\leq 35$ & 6 & 7.5 & 51.31 & 10.1 & 30 & 75 \\
\hline & Middle aged & $36-50$ & 38 & 47.5 & & & & \\
\hline & Old & $>50$ & 36 & 45 & & & & \\
\hline \multirow{5}{*}{$\begin{array}{l}\text { Education } \\
\text { (Year of schooling) }\end{array}$} & Illiterate & 0 & 0 & 0 & 6.05 & 3.7 & 1 & 12 \\
\hline & Primary & 1 to 5 & 34 & 42.5 & & & & \\
\hline & Secondary & 6 to 10 & 43 & 53.8 & & & & \\
\hline & Higher secondary & 11 to 12 & 3 & 3.8 & & & & \\
\hline & Graduate or above & $>12$ & 0 & 0 & & & & \\
\hline \multirow{3}{*}{$\begin{array}{l}\text { Farming } \\
\text { experience(Year) } \\
\end{array}$} & Low experience & up to 20 & 22 & 27.5 & 29.88 & 13 & 5 & 62 \\
\hline & Medium experience & $21-40$ & 47 & 58.8 & & & & \\
\hline & High experience & $>40$ & 11 & 13.8 & & & & \\
\hline \multirow[t]{3}{*}{ Experience in rice cultivation(Year) } & Low experience & up to 20 & 26 & 32.5 & 29.1 & 13 & 5 & 60 \\
\hline & Medium experience & $21-40$ & 43 & 53.8 & & & & \\
\hline & High experience & $>40$ & 11 & 13.8 & & & & \\
\hline \multirow{3}{*}{$\begin{array}{l}\text { Experience in boro rice cultivation } \\
\text { (Year) }\end{array}$} & Low experience & up to 12 & 17 & 21.3 & 20.94 & 8.8 & 5 & 40 \\
\hline & Medium experience & $13-24$ & 31 & 38.8 & & & & \\
\hline & High experience & $>24$ & 32 & 40 & & & & \\
\hline \multirow[t]{3}{*}{ Family size } & Small & up to 4 & 60 & 75 & 4.16 & 1 & 3 & 7 \\
\hline & Medium & 5 to 6 & 17 & 21.3 & & & & \\
\hline & Large & $\geq 7$ & 3 & 3.8 & & & & \\
\hline \multirow{5}{*}{$\begin{array}{l}\text { Family Education } \\
\text { (Year of schooling) }\end{array}$} & Illiterate & 0 & 0 & 0 & 7.42 & 2.27 & 2.8 & 13 \\
\hline & Primary & 1 to 5 & 16 & 20 & & & & \\
\hline & Secondary & 6 to 10 & 58 & 72.5 & & & & \\
\hline & Higher secondary & 11 to 12 & 5 & 6.3 & & & & \\
\hline & Graduate or above & $>12$ & 1 & 1.3 & & & & \\
\hline \multirow[t]{5}{*}{ Farm size(ha) } & Landless & $<0.02$ & 0 & 0 & 0.41 & 0.2 & 0.1 & 1.1 \\
\hline & Marginal & $0.02-0.20$ & 5 & 6.3 & & & & \\
\hline & Small & $0.21-1.00$ & 73 & 91.3 & & & & \\
\hline & Medium & $1.01-3.00$ & 2 & 2.5 & & & & \\
\hline & Large & $>3.00$ & 0 & 0 & & & & \\
\hline Annual income $\left(000^{\prime} \mathrm{BDT}\right)$ & Low income & Up to 50 & 18 & 22.5 & 88.8 & 49 & 22 & 284 \\
\hline
\end{tabular}




\begin{tabular}{|c|c|c|c|c|c|c|c|c|}
\hline & Medium income & $51-100$ & 37 & 46.3 & & & & \\
\hline & High income & $>100$ & 25 & 31.3 & & & & \\
\hline \multirow[t]{4}{*}{ Organizational participation } & No participation & 0 & 11 & 13.8 & 1.28 & 0.8 & 0 & 3 \\
\hline & Low participation & $1-3$ & 69 & 86.3 & & & & \\
\hline & Medium participation & $4-6$ & 0 & 0 & & & & \\
\hline & High participation & $\geq 7$ & 0 & 0 & & & & \\
\hline \multirow[t]{4}{*}{ Cosmopoliteness } & No & 0 & 0 & 0 & 15.58 & 4.0 & 7 & 21 \\
\hline & Low & $1-8$ & 6 & 7.50 & & & & \\
\hline & Medium & $9-16$ & 30 & 37.50 & & & & \\
\hline & High & $>16$ & 44 & 55.00 & & & & \\
\hline \multirow[t]{4}{*}{ Exposure to communication media } & No exposure & 0 & 0 & 0 & 24.41 & 6.4 & 10 & 41 \\
\hline & Low & $1-24$ & 43 & 53.8 & & & & \\
\hline & Medium & $25-48$ & 37 & 46.3 & & & & \\
\hline & High & $>48$ & 0 & 0 & & & & \\
\hline \multirow[t]{2}{*}{ Training exposure } & Yes & & 52 & 65 & & & & \\
\hline & No & & 28 & 35 & & & & \\
\hline \multirow[t]{3}{*}{ Attitude } & Less favorable & up to 16 & 1 & 1.2 & 28.03 & 3.7 & 0 & 34 \\
\hline & Moderately favorable & $17-32$ & 77 & 95.1 & & & & \\
\hline & Highly favorable & $>32$ & 3 & 3.7 & & & & \\
\hline \multirow[t]{5}{*}{ Innovativeness(Year) } & Innovator & $<0.5$ & 0 & 0 & 3.25 & 1.6 & 1 & 9 \\
\hline & Early adopter & $0.5-1.75$ & 9 & 113 & & & & \\
\hline & Early majority & $>1.751-4.25$ & 57 & 71.3 & & & & \\
\hline & Late majority & $>4.251-5.50$ & 6 & 7.5 & & & & \\
\hline & Laggard & $>5.50$ & 8 & 10 & & & & \\
\hline
\end{tabular}

Table 2: Socio-economic characteristics of the respondents.

Extent of adoption of BRRI recommended boro rice varieties of the respondents

The scores on extent of adoption score of the respondents varied from 50 to 100 with a mean of 90.64 and standard deviation 14.46. Based on extent of adoption, the respondents were classified into low (up to 60), medium (60 - 80) and high (> 80) categories as shown in table 3.
Table 3 reveal that majority (77.5\%) of the respondents had high adoption followed by medium (16.3\%) and low (6.3\%) adoption. The findings also indicate that most (93.8\%) of the respondents of the study area had high to medium to low level of adoption. Islam [7] also found that that the highest proportion (74\%) of the farmers fell under the high adoption category with adoption of BRRI dhan29 production technologies by the farmers. 


\begin{tabular}{|c|c|c|c|c|c|c|c|}
\hline \multirow[b]{2}{*}{ Categories } & \multirow[b]{2}{*}{ Score } & \multicolumn{2}{|c|}{ Respondents $(\mathrm{N}=80)$} & \multirow[b]{2}{*}{ Mean } & \multirow[b]{2}{*}{ SD } & \multicolumn{2}{|c|}{ Range } \\
\hline & & Number & $\begin{array}{c}\text { Percentage } \\
(\%)\end{array}$ & & & Min & Max \\
\hline Low & up to 60 & 5 & 6.3 & 90.64 & 14.46 & 50 & 100 \\
\hline Medium & $60-80$ & 13 & 16.3 & & & & \\
\hline High & $>80$ & 62 & 77.5 & & & & \\
\hline Total & & 80 & 100 & & & & \\
\hline
\end{tabular}

Table 3: Distribution of the respondents according to their extent of adoption of BRRI recommended boro rice varieties.

Causes of adoption of BRRI recommended boro rice varieties

BRRI has recommended some varieties such as BRRI dhan47, BRRI dhan28, BRRI dhan29, BRRI dhan50, BR-26 etc. for cultivation in the coastal region. However, the farmers of the study area adopted only BRRI dhan 28 as boro rice for various causes.

\begin{tabular}{|l|c|c|c|c|}
\hline \multirow{2}{*}{$\begin{array}{l}\text { Serial } \\
\text { no }\end{array}$} & Causes of Adoption & \multicolumn{2}{|c|}{ Respondents (N=80) } & \multirow{2}{*}{ Rank } \\
\cline { 3 - 4 } & & Citation & $\begin{array}{c}\text { Percentage } \\
\text { order }\end{array}$ & \\
\hline 1. & Early maturity & 65 & 81.25 & $1^{\text {st }}$ \\
\hline 2. & $\begin{array}{c}\text { High market price } \\
\text { and good quality }\end{array}$ & 60 & 75.00 & $3^{\text {rd }}$ \\
\hline 3. & $\begin{array}{c}\text { Non-complexity of } \\
\text { cultivation proce- } \\
\text { dure }\end{array}$ & 62 & 77.50 & $2^{\text {nd }}$ \\
\hline 4. & $\begin{array}{c}\text { Less water require- } \\
\text { ment }\end{array}$ & 55 & 68.75 & $4^{\text {th }}$ \\
\hline
\end{tabular}

Table 4: Causes of adoption of BRRI recommended boro rice varieties.

Among these four causes, early maturity was the major reason for adopting BRRI dhan 28. Another important reason from the farmers' perspective was non- complexity of cultivation procedure. It indicates that from seed sowing to harvesting farmers' have to face less difficulty than other varieties. Farmer explained high market price and good quality as $3^{\text {rd }}$ reason as well as less water requiring as $4^{\text {th }}$ reason for adoption of BRRI dhan 28 .

Relationship between the selected characteristics of the respondents and their extent of adoption of BRRI recommended boro rice varieties

This section deals with the relationship between fifteen selected characteristics of the growers (farmers') and their extent of adoption of BRRI recommended boro rice varieties. To explore the rela- tionships between the selected characteristics of the respondents and their extent of adoption Pearson's product moment co-efficient of correlation (for interval and ratio type data) as well as Spearman rank correlation co-efficient(for ordinal type data) were used. The relationship of the selected characteristics of the respondents with their extent of adoption appears in table 5 .

\begin{tabular}{|c|c|c|c|}
\hline $\begin{array}{l}\text { Characteristics (Inde- } \\
\text { pendent variable) }\end{array}$ & $\begin{array}{c}\text { Dependent } \\
\text { variable }\end{array}$ & $\begin{array}{l}\text { Correlation } \\
\text { coefficient }\end{array}$ & $\begin{array}{l}\text { Re- } \\
\text { mark }\end{array}$ \\
\hline Age & \multirow{14}{*}{$\begin{array}{l}\text { Extent of } \\
\text { adoption }\end{array}$} & $-0.128 \mathrm{NS}$ & PPCC \\
\hline Educational qualification & & $0.024 \mathrm{NS}$ & PPCC \\
\hline Farming experience & & $-0.116 \mathrm{NS}$ & PPCC \\
\hline $\begin{array}{l}\text { Experience in rice culti- } \\
\text { vation }\end{array}$ & & $-0.135 \mathrm{NS}$ & PPCC \\
\hline $\begin{array}{l}\text { Experience in boro rice } \\
\text { cultivation }\end{array}$ & & $-0.150 \mathrm{NS}$ & PPCC \\
\hline Family size & & $0.022 \mathrm{NS}$ & PPCC \\
\hline Family education & & $-0.089 \mathrm{NS}$ & PPCC \\
\hline Farm size & & $0.053 \mathrm{NS}$ & PPCC \\
\hline Annual income & & $-0.011 \mathrm{NS}$ & PPCC \\
\hline Innovativeness & & $0.047 \mathrm{NS}$ & PPCC \\
\hline $\begin{array}{l}\text { Exposure to communica- } \\
\text { tion media }\end{array}$ & & $0.877^{* *}$ & SRCC \\
\hline $\begin{array}{l}\text { Organizational participa- } \\
\text { tion }\end{array}$ & & $-0.068 \mathrm{NS}$ & SRCC \\
\hline Cosmopoliteness & & $0.848^{* *}$ & SRCC \\
\hline $\begin{array}{l}\text { Attitude towards adop- } \\
\text { tion }\end{array}$ & & $0.003 \mathrm{NS}$ & SRCC \\
\hline
\end{tabular}

Table 5: Computed coefficient of correlation ( $r$ ) and spearman rank correlation between the selected characteristics of the respondents and their extent of adoption.

NS $=$ Non-significant $* *$. Correlation is significant at the 0.01 level (2-tailed) * Correlation is significant at the 0.05 level (2-tailed). PPCC = Pearson's Product Moment co-efficient of correlation. SRCC = Spearman Rank Correlation Coefficient. 
Findings indicate that among fifteen independent variables exposure to communication media and cosmopoliteness of the respondents showed a significant positive relationship with their extent of adoption while educational qualification, family size, farm size, innovativeness and attitude showed only positive relationship with their extent of adoption. It means that the more are the exposure to communication media and cosmopoliteness of the respondents the more are the farmers' extent of adoption of BRRI recommended boro rice varieties. Ahmed [8] also found that communication behavior and cosmopoliteness of the respondents had significant positive relationship with their adoption of selected wheat varieties. Aurangzeb [9] found there was positive relationship between education and adoption of integrated homestead farming technologies. Chowdhury [10] observed that family size of the farmers had positive and significant relationship with the adoption of selected BINA technologies. Hossen [11] found that farm size and innovativeness of the farmers had significant positive relationship with their adoption of intercropping with jackfruit by the farmers of Bhaluka upazila under Mymensingh district. Ahmed [8] found that the attitude towards wheat cultivation of the wheat growers had positive significant relationship with their adoption of selected wheat varieties.

\section{Conclusions}

Findings of the study and logical interpretation of their meaning in the light of other relevant facts it can be concluded that majority $(77.5 \%)$ of the respondents had high adoption followed by medium (16.3\%) and low (6.3\%) adoption. So we found that most (93.8\%) of the respondents of the study area had high to medium level of adoption. Among fifteen independent variables exposure to communication media and cosmopolitans of the respondents showed a significant positive relationship with their extent of adoption while educational qualification, family size, farm size, innovativeness and attitude showed only positive relationship with their extent of adoption. Respondents in the study area highly adopted only BRRI dhan28 mainly for two reasons such as early maturity and non-complexity of cultivation procedure.

\section{Bibliography}

1. Shelley IJ., et al. "Rice Cultivation in Bangladesh: Present Scenario, Problems, and Prospects". Journal of International Cooperation for Agricultural Development 14 (2016): 20-29.

2. Bangladesh Finance Bureau, Agricultural Statistics. Ministry of Agriculture, Government of the People's Republic of Bangladesh (2014).
3. BRRI (Bangladesh Rice Research Institute). About BRRI: A very short introduction, Bangladesh (2014).

4. Hossain M., et al. "Rice biodiversity in Bangladesh: Adoption, Diffusion and Disappearance of Varieties". Bangladesh Rural Advancement Committee, Research and Evaluation Division, Dhaka, Bangladesh (2013).

5. Ghosh MK. "Adoption of BRRI dhan28 in the Coastal Areas of Bangladesh". International Journal of Agricultural Extension and Rural Development Studies Department of Agricultural Extension and Rural Development, EXIM Bank Agricultural University, Bangladesh. 3.3 (2016): 25-35.

6. Ray GL. "Extension Communication and Management". Calcutta: Naya Prokash (1991).

7. Islam MZ. "Adoption of BRRI dhan29 Production Technologies by the Farmers". M.S. (Ag. Ext. Ed.) Thesis, Department of Agricultural Extension and Information System Sher-e-Bangla Agricultural University, Dhaka, Bangladesh (2007).

8. Ahmed B. "Adoption of Selected Wheat Varieties by the Farmers in Saintara Union under Dinajpur district". M.S. (Ag. Ext. Ed.) Thesis, Department of Agricultural Extension and Information System Sher-e-Bangla Agricultural University, Dhaka, Bangladesh (2006).

9. Aurangozeb MK. "Adoption of integrated homestead farming technologies by the rural women in RDRS, M.S. (Ag. Ext. Ed.) Thesis, Department of Agricultural Extension Education". Bangladesh Agricultural University, Mymensingh, Bangladesh (2002).

10. Chowdhury MSA. "Adoption of selected BINA technologies by the farmers of Boyra Union in Mymensingh District. M.S. (Ag. Ext. Ed.) Thesis". Department of Agricultural Extension Education, Bangladesh Agricultural University, Mymensingh, Bangladesh (1997).

11. Hossen MM. "Adoption of Intercropping with Jackfruit by the Farmers of Bhaluka up azilla under Mymenshing District". M.S. (Ag. Ext. Ed.) Thesis, Department of Agricultural Extension and Information System, Sher-e-Bangla Agricultural University, Dhaka, Bangladesh (2013).

\section{Volume 3 Issue 11 November 2019 (C) All rights are reserved by Manash Mohan Adhikary., et al.}

